\title{
Effect of Quantity of Soil Application of Zinc, Boron and Iron on Growth and Yield in Papaya cv. Red Lady
}

\author{
M. Preethi ${ }^{*}$, D.P. Prakash², Kulapati Hipparagi' ${ }^{1}$, I.B. Biradar ${ }^{3}$, \\ S.G. Gollagi ${ }^{4}$ and Shivayogi Ryavalad ${ }^{5}$
}

${ }^{1}$ Department of Fruit Science, College of Horticulture, Bagalkot- 587104, Karnataka, India

${ }^{2}$ Department of Fruit Science, College of Horticulture, Munirabad, Koppal, Karnataka, India

${ }^{3}$ Department of Agronomy, College of Horticulture, Arabhavi, Karnataka, India

${ }^{4}$ Department of Crop physiology, College of Horticulture, Bagalkot, Karnataka, India

${ }^{5}$ Department of Seed Science and Technology, RHREC, Bagalkot, Karnataka, India

*Corresponding author

A B S T R A C T

\begin{tabular}{|l|}
\hline Ke y w o r d s \\
Papaya, Red Lady, \\
Micronutrients, \\
Growth and Yield. \\
\hline Article Info \\
\hline Accepted: \\
21 August 2017 \\
Available Online: \\
10 September 2017
\end{tabular}

\section{Introduction}

Papaya (Carica papaya L.) is an important fruit crop of tropical world and has long been known as wonder fruit of the tropics. The highest productivity and its ability to produce fruits throughout the year have added to gain popularity and commercial importance. Besides this, papaya is a wholesome fruit with high nutritive value and therapeutic value. The fruit contains high amount of vitamin A, vitamin C and iron (Rashid et al., 1987). Ripe fruits are largely used as a fresh desert, while green fruits are often used in salads and pickles or cooked as a vegetable. Papain, a proteolytic enzyme present in the latex, collected mainly from the fruits, has various uses in the beverage, food, pharmaceutical and tanning industries. Also, papaya leaves have medicinal values. Because of these, papaya has been called as “common man's fruit".

Micronutrients play a major role in crop production due to their essentiality in plant metabolism and adverse effects that manifest 
due to their deficiency. These trace elements also play a major role in disease resistance in cultivated crop species. Furthermore, these micro-nutrients also help in uptake of major nutrients and play an active role in the plant metabolism process starting from cell wall development to respiration, photosynthesis, chlorophyll formation, enzyme activity, hormone synthesis, nitrogen fixation and reduction etc. (Das, 2003). Nevertheless, micronutrients can tremendously boost horticultural crop yield and improve quality and post-harvest life of horticultural produce (Raja, 2009). Hence, micronutrients are essentially as important as macronutrients to have better growth, yield and quality in plants. In spite of few studies have been taken up in papaya nutrition, there is very meager information about micronutrients in papaya. Further, agroclimatic zone wise, there will be a lot of difference in soils and their nutrient content. Also, as papaya grows and sets flowers and fruits continuously, it appears, there is a necessity of generation of information regarding requirement of quantity of each micronutrient. In this view, the present investigation was carried out to study the effect of quantity of soil application of $\mathrm{Zn}$, $\mathrm{B}$ and $\mathrm{Fe}$ on growth and yield in papaya cv. Red Lady.

\section{Materials and Methods}

The field experiment was conducted at Haveli, College of Horticulture, Bagalkot. The seeds of papaya (var. Red Lady) were sown in small polythene bags. Forty-five dayold seedlings of uniform size and vigour were planted within field during first week of July during morning in the pits of $45 \times 45 \times 45 \mathrm{~cm}$ dimension at a distance of $1.8 \mathrm{~m}$ in both directions. Soil application of fertilizers (250 g N, 250 g $\mathrm{P}$ and $500 \mathrm{~g} \mathrm{~K}$ per plant) were done in four equal split doses at two months interval starting from transplanting of seedlings. The experiment waslaid out in Randomized Block Design (RBD) with 14 treatments, which were replicated two times. The treatments were, $\mathrm{T}_{1}-3 \mathrm{~g}$ Zinc, $\mathrm{T}_{2}-5 \mathrm{~g}$ Zinc, $\mathrm{T}_{3^{-}}-10 \mathrm{~g}$ Zinc, $\mathrm{T}_{4}-15 \mathrm{~g}$ Zinc, $\mathrm{T}_{5}-2 \mathrm{~g}$ Boron, $\mathrm{T}_{6}$ $5 \mathrm{~g}$ Boron, $\mathrm{T}_{7}-8 \mathrm{~g}$ Boron, $\mathrm{T}_{8}-3 \mathrm{~g}$ Iron, $\mathrm{T}_{9}-5 \mathrm{~g}$ Iron, $\mathrm{T}_{10}-10 \mathrm{~g}$ Iron, $\mathrm{T}_{11}-15 \mathrm{~g}$ Iron, $\mathrm{T}_{12}-10 \mathrm{~g} \mathrm{Zn}$ $+5 \mathrm{~g} \mathrm{~B}+10 \mathrm{~g} \mathrm{Fe}, \mathrm{T}_{13}$-Ranadey Mixture $(20 \mathrm{~g})$, $\mathrm{T}_{14}$-Control (RDF only).The micronutrients soil applied at 1,3,5 and 7 months after transplanting. Observations on growth parameters (plant height, stem girth and number of leaves), reproductive parameters (number of flowers and fruits per plant), fruit parameters (weight of fruits, fruit length and width) and yield parameters ( $\mathrm{kg} \mathrm{plant}^{-1}$ and tonnesha $^{-1}$ ) were recorded at eight months after transplanting.

Plant height was recorded by using scale. A mark was made in the trunk, ten $\mathrm{cm}$ above the ground level as a reference point. The plant height was recorded from this reference point to the tip of the growing shoot. Stem girth was recorded by using measuring tape. Number of leaves, flowers was recorded by visual counting. The number of fruits per plant was physically counted after maturity and was expressed as numbers per tree. Five randomly selected papaya fruits were weighed using digital analytical balance and the average value of fruit was expressed in kilo grams. Fruit length and width in each treatment was measured with the help of scale and it was expressed in centimeters $(\mathrm{cm})$. The fruit yield was recorded at the time of harvest and expressed in kilograms per plant. The fruit yield per hectare was computed by multiplying the yield per plant with the number of plants that can be accommodated in one hectare and was expressed in tonnes per hectare.

\section{Results and Discussion}

The vegetative parameters such as plant height and stem girth at 8 months after transplanting showed non-significant differences and number of leaves showed 
significant differences with micronutrient treatments (Table 1). However, maximum plant height $(1.52 \mathrm{~m})$ and stem girth $(35.97$

$\mathrm{cm})$ and highest number of leaves (41.34) were recorded with the treatment $\mathrm{T}_{12}(10 \mathrm{~g} \mathrm{Zn}$ $+5 \mathrm{~g} \mathrm{~B}+10 \mathrm{~g} \mathrm{Fe}$ ) whereas no micronutrient treatment recorded minimum values of vegetative parameters. The increased vegetative parameters is due to the application of micronutrients like $\mathrm{Zn}, \mathrm{Fe}$ and $\mathrm{B}$ which influence on growth attributes and improved photosynthetic efficiency and respiration of plant. The zinc sulphate on enhancing the vegetative growth may be ascribed for role of zinc in synthesis of tryptophan, which is the precursor of auxin as confirmed by Singh et al., (2010) in papaya. The combinations of boron and zinc increased the metabolites activities, which lead to increase plant metabolites responsible for cell division, cell elongation and plant growth (Bhalerao and Patel, 2015). Fe is also necessary for vital plant metabolic functions such as chlorophyll synthesis, enzymatic reactions, respiration and photosynthesis. In addition, boron regulates metabolism involved in translocation of carbohydrates and cell wall development. The results are in close conformity with the findings of Ram and Bose (2000).
On the contrary, the days taken for flowering, fruit set and fruit harvest after fruit set (Table 2) was utmost advanced (days) under the treatment receiving boron $8 \mathrm{~g}(103.00,122.83$ and 146.83 days respectively). This earliness may be due boron plays vital role in early flower initiation, flower bud formation and production of indigenous and florigenic substances. Besides stimulation of pollen germination, growth of pollen tube, fertilization process, it also involved in glucose metabolism, hydrocarbons and their transport. Similar findings were in conformity with the findings of Singh et al., (2010) in cv. Ranchi. With respect to reproductive parameters, the plants treated with soil application of $\mathrm{T}_{12}(10 \mathrm{~g} \mathrm{Zn}+5 \mathrm{~g} \mathrm{~B}+10 \mathrm{~g} \mathrm{Fe})$ showed higher number of flowers plant ${ }^{-1}$ (49.50) at 8 months after transplanting (Table 1). It may be due to the positive combined effect of zinc, iron and boron on flowering. Zinc enhanced the synthesis of auxin in plants which stimulate the flowering (Ryugo, 1988). Iron is credited with a definite role in the synthesis of chlorophyll molecule (Pandey and Sinha, 2006). Boron regulates metabolism involved in translocation of carbohydrates, cell wall development and RNA synthesis (Brown et al., 1995).Similar results were observed by Venu et al., (2014) in kagzi lime.

Table.1 Effect of micronutrients on growth parameters at eight months after transplanting

\begin{tabular}{|c|c|c|c|c|c|c|}
\hline \multicolumn{2}{|r|}{ Treatment } & Plant height (m) & Stem girth $(\mathrm{cm})$ & Leaves plant $^{-1}$ & Flowers plant $^{-1}$ & Fruits plant $^{-1}$ \\
\hline $\mathrm{T}_{1}$ & $3 \mathrm{~g}$ Zinc & 1.25 & 31.95 & 29.5 & 34.17 & 23.42 \\
\hline $\mathrm{T}_{2}$ & $-\quad 5 \mathrm{~g}$ Zinc & 1.32 & 32.75 & 28.5 & 38 & 23.67 \\
\hline $\mathrm{T}_{3}$ & - $\quad 10 \mathrm{~g}$ Zinc & 1.38 & 34.78 & 29 & 38.67 & 24 \\
\hline $\mathrm{T}_{4}$ & $-\quad 15 \mathrm{~g}$ Zinc & 1.43 & 34.92 & 35.5 & 42.83 & 27 \\
\hline $\mathrm{T}_{5}$ & - $\quad 2 \mathrm{~g}$ Boron & 1.25 & 30.23 & 27.17 & 34.33 & 23.83 \\
\hline $\mathrm{T}_{6}$ & $-\quad 5 g$ Boron & 1.27 & 32.52 & 27.5 & 34.17 & 24.33 \\
\hline $\mathrm{T}_{7}$ & - $8 \mathrm{~g}$ Boron & 1.38 & 34.1 & 28 & 38.17 & 24.5 \\
\hline $\mathrm{T}_{8}$ & $-\quad 3 g$ Iron & 1.26 & 32.12 & 27.67 & 38.5 & 23.5 \\
\hline $\mathrm{T}_{9}$ & $-\quad 5 \mathrm{~g}$ Iron & 1.37 & 32.93 & 28.17 & 39.5 & 22.33 \\
\hline & $-\quad 10 \mathrm{~g}$ Iron & 1.4 & 34.9 & 35.17 & 40.33 & 25.34 \\
\hline $\mathrm{T}_{11}$ & - $15 \mathrm{~g}$ Iron & 1.38 & 34.85 & 27.17 & 39.67 & 24.34 \\
\hline $\mathrm{T}_{12}$ & $-\quad 10 \mathrm{~g} \mathrm{Zn}+5 \mathrm{~g} \mathrm{~B}+10 \mathrm{~g} \mathrm{Fe}$ & 1.52 & 35.97 & 41.34 & 49.5 & 28.67 \\
\hline & - $\quad$ Ranadey Mixture (20g) & 1.47 & 32.55 & 28.84 & 36.33 & 23.33 \\
\hline & - Control (RDF only) & 1.23 & 29.4 & 26.67 & 33.67 & 20.67 \\
\hline S E & & 0.07 & 2.02 & 1.75 & 2.16 & 1.12 \\
\hline CD & $5 \%$ & NS & NS & 5.34 & 6.59 & 3.41 \\
\hline
\end{tabular}


Table.2 Effect of micronutrients on days to first flowering, fruit set and Fruit harvest after fruit set

\begin{tabular}{|c|c|c|c|c|}
\hline & Treatment & $\begin{array}{l}\text { Days taken for } \\
\text { first flowering }\end{array}$ & $\begin{array}{l}\text { Days taken to } \\
\text { first fruit set }\end{array}$ & $\begin{array}{c}\text { Days to fruit } \\
\text { harvest after fruit } \\
\text { set }\end{array}$ \\
\hline $\mathrm{T}_{1}$ & - $\quad 3 g$ Zinc & 110.17 & 136.67 & 158.00 \\
\hline $\mathrm{T}_{2}$ & - $\quad 5 g$ Zinc & 109.67 & 136.33 & 157.17 \\
\hline $\mathrm{T}_{3}$ & - $\quad 10 \mathrm{~g}$ Zinc & 110.17 & 136.83 & 154.67 \\
\hline $\mathrm{T}_{4}$ & - $\quad 15 \mathrm{~g}$ Zinc & 110.33 & 137.50 & 149.67 \\
\hline $\mathrm{T}_{5}$ & - $\quad 2 \mathrm{~g}$ Boron & 109.17 & 126.33 & 153.17 \\
\hline $\mathrm{T}_{6}$ & - $\quad 5 \mathrm{~g}$ Boron & 108.67 & 123.33 & 150.17 \\
\hline $\mathrm{T}_{7}$ & - $8 \mathrm{~g}$ Boron & 103.00 & 122.83 & 146.83 \\
\hline $\mathrm{T}_{8}$ & - $\quad 3 g$ Iron & 109.67 & 135.33 & 157.83 \\
\hline $\mathrm{T}_{9}$ & - $5 \mathrm{~g}$ Iron & 110.00 & 137.50 & 156.67 \\
\hline $\mathrm{T}_{10}$ & - $10 \mathrm{~g}$ Iron & 110.83 & 137.67 & 155.33 \\
\hline $\mathrm{T}_{11}$ & - $15 \mathrm{~g}$ Iron & 111.67 & 138.00 & 156.50 \\
\hline $\mathrm{T}_{12}$ & $-10 \mathrm{~g} \mathrm{Zn}+5 \mathrm{~g} \mathrm{~B}+10 \mathrm{~g} \mathrm{Fe}$ & 107.67 & 123.00 & 147.17 \\
\hline & - Ranadey Mixture (20g) & 108.50 & 126.00 & 156.33 \\
\hline $\mathrm{T}_{14}$ & - Control (RDF only) & 114.67 & 145.17 & 161.17 \\
\hline \multicolumn{2}{|c|}{ 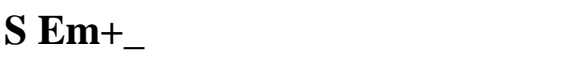 } & 1.13 & 0.56 & 0.54 \\
\hline \multicolumn{2}{|c|}{ CD@5\% } & 3.45 & 1.71 & 1.64 \\
\hline
\end{tabular}

Table.3 Effect of micronutrients on fruit and fruit yield parameters in papaya

\begin{tabular}{|c|c|c|c|c|c|c|}
\hline & Treatment & $\begin{array}{c}\text { Fruit } \\
\text { weight(kg) }\end{array}$ & $\begin{array}{l}\text { Fruit length } \\
(\mathrm{cm})\end{array}$ & $\begin{array}{c}\text { Fruit width } \\
(\mathrm{cm})\end{array}$ & $\begin{array}{c}\text { Yield (kg } \\
\text { plant }^{-1} \text { ) }\end{array}$ & $\begin{array}{c}\text { Yield } \\
\left(\mathrm{t} \text { ha }^{-1}\right)\end{array}$ \\
\hline $\mathrm{T}_{1}$ & $3 \mathrm{~g}$ Zinc & 1.16 & 15.3 & 10.68 & 26.97 & 83.23 \\
\hline $\mathrm{T}_{2}$ & $-\quad 5 \mathrm{~g}$ Zinc & 1.18 & 16.65 & 10.85 & 28.01 & 86.44 \\
\hline $\mathrm{T}_{3}$ & - $\quad 10 \mathrm{~g}$ Zinc & 1.17 & 17.55 & 11.6 & 28.04 & 86.53 \\
\hline $\mathrm{T}_{4}$ & - $\quad 15 \mathrm{~g}$ Zinc & 1.35 & 18.6 & 11.75 & 36.30 & 112.02 \\
\hline $\mathrm{T}_{5}$ & - $\quad 2 \mathrm{~g}$ Boron & 1.12 & 16.65 & 10.78 & 26.46 & 81.65 \\
\hline $\mathrm{T}_{6}$ & - $5 \mathrm{~g}$ Boron & 1.14 & 16.9 & 11.18 & 27.63 & 85.26 \\
\hline $\mathrm{T}_{7}$ & - $8 \mathrm{~g}$ Boron & 1.15 & 17.6 & 11.35 & 28.23 & 87.13 \\
\hline $\mathrm{T}_{8}$ & $-3 \mathrm{~g}$ Iron & 1.2 & 15.5 & 11.6 & 28.09 & 86.70 \\
\hline $\mathrm{T}_{9}$ & $-5 \mathrm{~g}$ Iron & 1.22 & 17.13 & 11.75 & 27.12 & 83.68 \\
\hline $\mathrm{T}_{10}$ & - $10 \mathrm{~g}$ Iron & 1.34 & 17.75 & 12 & 33.80 & 104.30 \\
\hline $\mathrm{T}_{11}$ & - $15 \mathrm{~g}$ Iron & 1.36 & 17.5 & 11.55 & 33.00 & 101.83 \\
\hline $\mathrm{T}_{12}$ & $-10 \mathrm{~g} \mathrm{Zn}+5 \mathrm{~g} \mathrm{~B}+10 \mathrm{~g} \mathrm{Fe}$ & 1.54 & 20.95 & 13.5 & 43.99 & 135.77 \\
\hline $\mathrm{T}_{13}$ & - Ranadey Mixture (20g) & 1.14 & 16.8 & 11.68 & 26.47 & 81.69 \\
\hline $\mathrm{T}_{14}$ & - Control (RDF only) & 1.1 & 14.45 & 10.6 & 22.74 & 70.17 \\
\hline S Em & & 0.03 & 0.94 & 0.45 & 1.39 & 4.29 \\
\hline CD & $5 \%$ & 0.09 & 2.87 & 1.36 & 4.25 & 13.11 \\
\hline
\end{tabular}


Significantly highest number of fruits were recorded in $T_{12}(28.67)$ which was on par with treatments $\mathrm{T}_{4}(27.00)$ and $\mathrm{T}_{10}(25.34)$, whereas least number of fruits were found in $\mathrm{T}_{14}(\mathrm{Control})$.The increase in number of fruits per tree due to combined application of micronutrients either through foliar or soil application might be due to production of auxins which were probably helpful for retention of fruits by reducing flower drops there by increasing number of fruits. The result was in agreement with the findings of Tamboli et al., (2015) in fig. Similar results were also found by in Dhinesh et al., (2007) Kinnow mandarin. The results showed highest values for weight of fruits $(1.54 \mathrm{~kg})$, fruit length $(20.95 \mathrm{~cm})$ and width $(13.50 \mathrm{~cm})$ in the plants treated with $10 \mathrm{~g}$ Zinc $+5 \mathrm{~g}$ Boron $+10 \mathrm{~g}$ Iron $\left(\mathrm{T}_{12}\right)$. However, fruit length on par with $\mathrm{T}_{4}(18.6 \mathrm{~cm})$. However, the lowest values were observed in control (Table 3). Cumulative effect of combined treatment of zinc, boron and iron might have resulted into higher fruit weight. The possible reason for increase in fruit weight by the micronutrients might be due to faster loading and mobilization of photo assimilates to fruits and involvement in cell division and cell expansion which ultimately reflected into more weight of fruit in treated plants (Gurjar et al., 2015). Similar results were also found by Banik et al., (1997), Dutta and Dhua (2002), Dutta (2004) in mango and Ghanta and Mitra (1993) in banana which are in agreement with the present findings. The increase in fruit length was possibly due to accumulation of more food material in the tree that lead to efficient utilization for fruits development (Ram and Bose, 2000). The highest values for mean fruit yield per plant was recorded in $\mathrm{T}_{12}(43.99 \mathrm{~kg})$ in the same way highest yield ha ${ }^{-1}$ was recorded in $\mathrm{T}_{12}$ (135.77 tonnes) whereas, significantly least values were recorded in control (Table 3). Micronutrients played a pivotal role in vegetative growth, flowering, development of plants and are also directly involved in the process of photosynthesis, this means that a possibility of increasing dry matter percentage as well as yield. These results are in conformity with the findings of Tamboli et al., (2015) in fig. The beneficial effects of micronutrients on growth and nutrition were also observed by earlier workers in sapota (Saraswathy et al., 2004), in Kinnowmandrian (Dhinesh et al., 2007), in mandarin orange (Saraswathi et al., 1998) and in guava (Rathore et al., 2008). The findings of the study indicated the importance of zinc, boron and iron to increase the plant growth and yield in papaya cv. Red Lady.

\section{References}

Banik, B. C., Mitra, S. K., Sen, S. K. and Bose, T. K., 1997, Interactions effects of zinc, iron and boron sprays on flowering and fruiting of mango $\mathrm{cv}$. Fazli. Indian Agric., 41 (3): 187-192.

Bhalerao, P. P., and Patel, B. N., 2015, Effect of foliar application of $\mathrm{Ca}, \mathrm{Zn}, \mathrm{Fe}$ and $\mathrm{B}$ on growth, yield and quality of papaya var. Taiwan Red Lady. Indian J. Hort., 72(3): 325-328.

Brown, P. H., Ferguson, L. and Piccioni, G., 1995, Boron boosts pistachio yields. Fluid J., 33(1): 53-55.

Das, D. K., 2003, Micronutrients: Their behaviors in soils and plants, Kalyani Publ., Ludhiana, pp.111-214. Easterwood.

Dhinesh, B. K., Dubey, A. K. and Yadav, D. S., 2007, Effect of micronutrients on enhancing the productivity and quality of Kinnow mandarin. Indian J. Hort., 64(3): 353-356.

Dutta, P., 2004, Effect of foliar boron application on panicle growth, fruit retention and physico- chemical characters of mango cv. Himsagar. Indian J. Hort., 61(3): 265-266.

Dutta, P., and Dhua, R. S., 2002, 
Improvement on fruit quality of Himsagar mango through application of zinc, iron and manganese. Hortic. J., 15(2): 1-9.

Ghanta, P. K., and Mitra, S. K., 1993, Effect of micronutrients on growth, flowering, leaf nutrient content and yield of banana cv. Giant Governor. Crop Res., 6(2): 284-287.

Gurjar, M. K., Kaushik, R. A. and Baraily. P., 2015, Effect of zinc and boron on the growth and yield of kinnow mandarin. Int. J. Scientific Res., 4(1): 207-208.

Pandey, S. N., and Sinha, B. K., 2006, Plant Physiology, $4^{\text {th }}$ edition Vikas Publication House, Nodia; pp 130-135.

Raja, E. M., 2009, Importance of micronutrients in the changing horticultural scenario. J. Hort. Sci., 4 (1): 1-27.

Ram, R. A., and Bose, T. K., 2000, Effect of foliar application of magnesium and micronutrients on growth, yield and fruit quality of mandarin orange (Citrus reticulate Blanco). Indian J. Hort., 57(3): 215-220.

Rashid, M. M., Quadir, M. A. and Hossain, M. M., 1987, BangladesherPhal (Fruit of Bangladesh).Rashid Publishing House. Bangladesh Agril Res. Inst. Campus. Gazipur. pp. 130-137.

Rathore, N.S., Dashora, L.K. and Sarolia, D.K., 2008, Effect of zinc and boron on yield and quality of guava (Psidium guajava L.) cultivar 'Sardar' under
Mewar region. Dept. of Hort.

Ryugo, K., 1988, Fruit culture. John Wiley and Sons p. 259- 261.

Saraswathi, T., Thangaraj, T., Azhaklamanavalan, R.S. and Balakrishnamurthy, G. 1998, Effect of micronutrients on yield and quality of mandarin orange (Citrus reticulate Blanco). South Indian Hort., 46: 12831.

Saraswathy, S., Balakrishnan, K., Anbu, S., Azakia, Manavalan, R. S. and Thangaraj, T., 2004, Effect of zinc and boron on growth, yield and quality of sapota cv. PKM-1. South Indian Hort., 52(1-6): 41-44.

Singh, D. K., Ghosh, S. K., Paul, P. K. and Suresh, C. P., 2010, Effect of different micronutrients on growth, yield and quality of papaya (Carica papayaL.) cv. Ranchi. Acta Hort., 8(2): 37-41.

Tamboli, B. D., Sawale, D. D., Jagtap, P. B., Nimbalkar, R. U. and Teke, S. R., 2015, Effect of micronutrients on yield and fruit quality of fig on Inceptisol. Indian J. Hort., 72 (3): 419-422.

Venu, A., Delvadia, D. V., Sharma, L. K., Gardwal, P.C. and Makhmale, S., 2014, Effect of micronutrient application on flowering, fruiting and yield of acid lime (Citrus aurantifolia L.) cv. Kagzi lime. Int. J. Tropi. Agric. Serials Publications, 32 (3-4): 331-334.

\section{How to cite this article:}

Preethi, M., D.P. Prakash, Kulapati Hipparagi, I.B. Biradar, S.G. Gollagi and Shivayogi Ryavalad. 2017. Effect of Quantity of Soil Application of Zinc, Boron and Iron on Growth and Yield in Papaya cv. Red Lady. Int.J.Curr.Microbiol.App.Sci. 6(9): 2081-2086. doi: https://doi.org/10.20546/ijcmas.2017.609.255 